\title{
ENHANCING JUROR EFFECTIVENESS: AN INSURER'S PERSPECTIVE
}

\author{
Judyth W. Pendell* \\ I \\ INTRODUCTION
}

Over the past few years, Aetna and other insurers have been under fire from some critics ${ }^{1}$ for their interest in civil justice reform. Insurers have been cast as profiteering opportunists, who have invented civil justice reform as a device to mask problems that result from their business practices. The reality is that the civil justice system has witnessed a considerable change in tort and contract law over the last two decades. The increasing unpredictability, rising costs, and growing inefficiency of litigation have wreaked havoc with the ability of businesses and governments to provide needed products and services at affordable prices, and in some cases to provide them at all. ${ }^{2}$ The insurance industry has been greatly affected. To respond to customer concerns over rising premiums and limitations on liability coverages, Aetna has engaged in an intensive effort to develop a better understanding of the liability system and to develop and advance reforms that improve the system in a way that balances the interests of all parties. ${ }^{3}$

The issue of juror effectiveness is of particular interest to Aetna. It is one of the areas where the interests of society and litigating parties align rather closely with what facilitates the insurance industry's ability to provide affordable liability insurance. If juries execute their responsibilities as charged, apply the law as directed, and reach rational and unbiased conclusions regarding the facts, they both uphold the objectives and principles of the justice system and fairly serve the litigating parties' interests. Under these circumstances, and assuming a situation where the law to be

\footnotetext{
Copyright $(\mathcal{O} 1989$ by Law and Contemporary Problems

* Assistant Vice President, Law and Public Affairs, Aetna Life \& Casualty, supervising Aetna's civil justice reform efforts.

1. A recent critic's views are presented in Daniels' article in this issue of Law and Contemporary Problems. Daniels, The Question of Jury Compesence and the Politics of Civil Justice Reform: Symbols, Rhetoric, and Agenda-Building, Law \& Contemp. Probs., Autumn 1989, at 269.

2. See Committee for Economic Development, Who Should be Liable? (1989); P. Huber, Liability: The Legal Revolution and Its Consequences (1988).

3. Aetna's efforts have focused on the problems associated with: unjustified suits; the excessive transaction costs of litigation; the burdens imposed on courts; the impact of the system on the availability and affordability of products, and on innovation and safety; the fairness of tort doctrines; and juror effectiveness, to name just some of the issues.
} 
applied is clear and stable, ${ }^{4}$ juries also produce fairly predictable outcomes. Notwithstanding the limited empirical evidence on the effect of predictable outcomes, there is little doubt that predictability greatly facilitates settlement by narrowing the gap between plaintiffs' and defendants' judgments about their probability of success at trial and the likely size of the award. Early settlements in turn reduce transaction costs, more quickly compensate plaintiffs, relieve the parties of the uncertainty that accompanies an unresolved lawsuit, and minimize the demands upon the courts. Predictable trial outcomes also assist insurers in their ability to price liability products with confidence, thereby reducing the amount of money they must set aside to provide for the unexpected.

Some critics of the jury system have little faith in its value. Dean Erwin N. Griswold stated the following in a 1962-63 report to Harvard Law School: "The jury trial at best is the apotheosis of the amateur. Why should anyone think that 12 persons brought in from the street, selected in various ways for their lack of general ability, should have any special capacity for deciding controversies between persons?"'5 Connecticut Superior Court Judge Robert Satter writes that the trial process itself offers little assistance, since "[e]verything about a trial is designed to manipulate, confuse and confound juries." 6

Despite these shortcomings, Aetna is not ready to give up on the jury system. ${ }^{7}$ There is, however, a need for objective and credible research on how juries function and how they can be helped to function better. There is also a need to use the devices that seem to aid jury performance, such as: allowing jurors to take notes; providing jurors with a pretrial instruction of the issues to be addressed; providing jurors with a written copy of the charge; severing the issues for trial; using court-appointed experts; and using blue ribbon juries. This paper will cover some of the research that may be helpful to an understanding of the jury process and will discuss the aids that could improve jury functioning.

\section{AsSESSING JURor EfFEctiveness}

Assessing juror effectiveness is not a simple matter. Two approaches for making an assessment involve: (1) looking at jury outcomes and measuring

4. The instability of the law in the areas of product liability, environmental liability, professional malpractice, and employment relations is a problem not addressed in this paper. See generally P. HuBER, supra note 2.

5. Satter, Why Civil Juries Don't Work, 15 Conn. L. Tribune, Nov, 27, 1989, at 1.

6. Id. at 10. Satter advocates addressing this confusion through bifurcating the issues at trial. If after hearing testimony on liability, the jury finds for the plaintiff, and the parties are unable to settle, the plaintiff can propose a full hearing on the damages. Prior to a determination of damages by the jury, however, he suggests that the parties each submit to the judge a figure they consider reasonable in light of what they have heard in the trial. The judge would relay the two figures to the jury and requnre the jury to pick one of the figures as their award.

7. It should be mentioned that no-fault systems for certain categories of cases, such as auto and workplace injuries, appear to be a more efficient and sensible method for providing compensation. 
them against some standard of reasonableness; and (2) studying how jurors react to the information they are given and reach a decision.

There are some obvious problems associated with setting a standard of reasonableness for jury outcomes. Acceptable measures of reasonableness are likely to vary considerably between plaintiffs and defendants, and even within the judiciary. One interesting and relevant experiment involved an informal effort by a Connecticut judge to keep an ongoing record of the plaintiff's demand, the defendant's offer, and the jury verdict for each case tried in his courthouse. ${ }^{8}$ In the period from 1984 to 1988, plaintiffs prevailed in 101 cases. In 59 percent of these cases, the verdict amount was either higher than the plaintiff's demand or lower than the defendant's offer. These results suggest that verdicts in this court are not very predictable; it further suggests that the outcomes may not be reasonable even by the standards of the parties whose interests are served. There is a need for research of this type on a broader scale.

A Louis Harris \& Associates poll ${ }^{9}$ of 800 state and 200 federal trial court judges asked whether juries should receive judicial guidelines for the amount of damages to be awarded. The responses suggest that, without this assistance, juries are not doing as well as they might in arriving at reasonable damage figures. Eighty percent of the federal judges and 62 percent of the state judges responded that they would favor having judges provide this guidance in some or all civil cases. ${ }^{10}$ Further, Judge Satter concludes on the basis of his own experience that "jury damage awards are erratic. While some are sensible, others are senseless and even irrational."'1

Most research on the jury process has involved the study of shadow or mock juries. ${ }^{12}$ Although these devices appear to be useful tools for understanding the process by which jurors reach conclusions, it is questionable whether mock juries can be treated as surrogates for actual trial juries. ${ }^{13}$ One thorough study by the RAND Institute for Civil Justice of an actual asbestos trial in a U.S. district court involved extensive postverdict interviews with the six-person jury. ${ }^{14}$ In this case, claims of asbestosis by four plaintiffs resulted in a damage award of $\$ 7.9$ million against ten asbestos manufacturers. After observing the trial and questioning the jurors about their deliberations, the interviewers drew the following conclusions:

8. Satter, supra note 5 , at 11 .

9. Louis Harris \& Associates, Inc., Judges' Opinions on Procedural Issues: A Survey of State and Federal Trial Judges Who Spent at Least Half Their Time on General Civil Cases, 69 B.C.L. Rev. 731 (1989).

10. Id. at 750 .

11. See Satter, supra note 5, at 11.

12. A shadow jury is an experiment in which participants observe an actual trial and then simulate the deliberations. A mock jury is an experiment in which both the trial and the deliberations are simulated.

13. A number of problems are associated with shadow and mock jury experiments. The lack of real consequences may adversely affect attention spans and the group dynamics of the deliberation process. Frequent debriefings may emphasize the artificial aspect of the situation and affect jurors' responses. Also, the subjects may not be representative of actual jury pools. M. SELvin \& L. Picus, The Debate over Jury Performance: Observations from a Recent Asbestos Case 42 n.2 (1987).

14. Id. 
Individual jurors apparently left the trial with a general memory that asbestos is a dangerous substance, but the jury's collective memory of the specific scientific and medical information about asbestosis presented contained several errors. The jurors' failure to understand, for example, that not everyone exposed to asbestos develops asbestosis and their belief that each of the plaintiffs would eventually become as sick as the sickest plaintiff were of major consequence in their computation of compensatory awards. . . . [The] jurors seemed to have formed opinions as to the merits of a witness's testimony or an attorney's argument based not only on the substance of the testimony or evidence presented but also on their perception of that individual's characteristics, personality and behavior. The ethnicity of one plaintiff, the jury's general skepticism of the defense's medical experts (fueled partly by its perception of the income these experts earned), and the large number of attorneys who appeared for the defendants all may have influenced both the jury's finding of liability and variation in the size of the four compensatory awards it made. . . [The] jurors had difficulty in three instances remembering and following the judge's instructions. They applied evidence incorrectly, awarded compensation for expenses they were not supposed to consider, and considered extralegal factors in determining liability and punitive awards. ${ }^{15}$

Although a study of one jury is hardly dispositive of jury effectiveness, as the authors indicate, it provides a useful reference point against which to compare previous, largely experimental research. Prior research indicates that jurors essentially lack accurate memories for trial testimony, have trouble making decisions on the basis of statistical or probabilistic information, often enter into deliberations with a tentative belief about guilt or liability, and often deviate from the judge's instructions. ${ }^{16}$ Nevertheless, juries can be helped not only to understand better what is expected of them, but also to comprehend and retain more effectively the information they receive at trial.

\section{III}

\section{Notetaking/Preinstruction/Written Charge}

The growth of complex litigation, with its many litigating parties, highly complicated issues of fact and law, and protracted trials, has prompted many judges to experiment with ways to make the job of a juror easier. One of these is to allow jurors to take notes. Opponents of juror notetaking argue that the skilled notetaker is likely to dominate the deliberations in an inappropriate way and to appear more knowledgeable of the facts of the case. They also argue that inaccurate notes might be accepted as fact, that the activity of notetaking might be distracting, and that notes may be incomplete because the pace of the trial may make it impossible to take complete notes.

Research does not support these concerns. One recent study conducted under the auspices of the Judicial Council of Wisconsin found that notetaking was not distracting, that notetakers were not overly influential during the 
deliberations, and that the jurors' notes were for the most part accurate. ${ }^{17}$ Other studies have come to similar conclusions. ${ }^{18}$

Research findings about the usefulness of notetaking as a memory aid are somewhat mixed. Several studies have found them useful, ${ }^{19}$ although the Wisconsin study did not. This contradiction is not troubling. The evidence that notetaking does not appear to have any adverse consequences leads to the conclusion that this practice is justified on the basis of its potential benefits. Notetaking seems very practical, considering the vast amount of information some juries are asked to evaluate and the wastefulness of the fishing expeditions through transcripts that occur when jurors cannot remember just when in the trial they heard the information they need.

Pretrial juror instructions can also provide guidance to the jury before the trial begins. The preinstruction must be carefully crafted to include only those legal principles whose applicability to the case cannot reasonably be questioned. The advantages of this practice are as follows:

(1) it can aid attentiveness and memory processes, since jurors know what they should be looking for;

(2) it can help jurors link evidence to the relevant issues;

(3) it may allow jurors to identify personal biases that bear on the matter at trial, helping them deal with the biases more effectively; and

(4) when offered on the evaluation of credibility or the nature of reasonable inferences, it may enable jurors better observe the testimony and evidence. ${ }^{20}$

Finally, supplying jurors with a postdelivery copy of the charge can be useful. In one study of fourteen trials where written copies of the charge were given to juries, the participating judges found the procedure to be very helpful in twelve of the trials evaluated. ${ }^{21}$ The value seems to increase with the complexity of the trial. ${ }^{22}$ In light of the research that indicates juries may have problems following the judges' instructions, it only makes sense to take this step to increase the likelihood that the jury will understand its charge.

\section{Issue Severance}

Juries typically hear all issues in one unified trial. This process often results in a marathon of expert witnesses and exhibits on a diverse set of

17. Heuer \& Penrod, Increasing Jurors 'Participation in Trial: A Field Experiment with Jury Notetaking and Question Asking, 12 LAw \& Hum. BeHAV. 231, 247-51 (1988).

18. See, e.g., Falango, Would Jurors Do a Better Job if They Could Take Notes?, 63 Judicature 437 (1980); Sand \& Reiss, A Report on Seven Experiments Conducted by District Court Judges in the Second Circuit, 60 N.Y.U. L. REV. 423, 446-53 (1984).

19. Sand \& Reiss, supra note 18 , at $450-51$.

20. Id. at $437-43$.

21. Id. at 454-55.

22. Since this practice does add to the workload of judges, it makes sense to limit it to cases where it is likely to make a meaningful difference. 
issues. Some trial judges have severed the issues for trial (for example, by bifurcating the issues of liability and damages). Narrowing the issues for consideration at any one time focuses and simplifies the task the jury is being asked to perform.

Issue severance has advantages beyond mitigating juror confusion. At a time when there is considerable concern over the high transaction costs associated with civil litigation ${ }^{23}$ and the growing backlog of cases in the courts, ${ }^{24}$ issue severance in the right cases makes sense. If liability or some other dispositive issue is heard first, and the jury finds for the defendant, the trial will terminate sooner. Experience also suggests that once a jury finds for the plaintiff on a dispositive issue, the parties are likely to settle. ${ }^{25}$ A quicker resolution of cases will both conserve the resources of the courts and considerably reduce the transaction costs to the parties.

Issue severance is most useful in cases where a lengthy trial is expected, particularly if complicated, technical, or scientific issues are involved. Longer trials are becoming more commonplace. In 1968, 26 percent of all civil trials in federal court took no more than a day to complete; in 1988, one-day trials represented only 14 percent of the caseload. ${ }^{26}$ In 1968, only 75 civil trials lasted for 10 days or more; in 1988, there were 359 such trials. ${ }^{27}$

The 1989 Louis Harris and Associates poll of the judiciary ${ }^{28}$ found strong support for bifurcating trials. Among judges who had used bifurcation, an overwhelming majority-84 percent at the federal and state levels-said that its effects were positive. ${ }^{29}$ Most judges believe that it reduces transaction costs (79 percent of the federal judges and 70 percent of the state judges), that it speeds up the trial process $(82$ percent of the federal judges and 77 percent of the state judges), and that it improves the fairness of the outcome (80 percent of the federal judges and 77 percent of the state judges). ${ }^{30}$ Yet bifurcation is not used very often, according to the poll. In the jurisdictions

23. See The Brookings Institute, Justice for All: Reducing Costs and Delay in Civil Litigation (1989).

24. Id.

25. Address by Clyde Adkins, Senior Judges' Committee of the American Bar Association (Aug. 5, 1988) (entitled "Litigation on the Fast Track/Clearing the Path to Settlement: A View from the Bench"). Atkins notes that Judge Hubert Will, Northern District of Illinois, has kept records of the trials he has bifurcated. Of the 152 cases he has bifurcated, only 25 had to be tried on the issue of damages. Also, Judge Satter indicates that in his experience, $90 \%$ of the cases will end in settlement after a verdict on liability for the plaintiff. Satter, supra note 5 , at 11.

26. Adler, Can Juries Do Justice to Complex Suits?, Wall St. J., Dec. 21, 1989, at B1, col. 4.

27. Id.

28. See Louis Harris \& Associates, Inc., supra note 9 and accompanying text.

29. Id. at 744 .

30. Id. at 745 . 
where bifurcation is permitted, ${ }^{31}$ most of the judges who have allowed bifurcation have done so fewer than five times over the previous three years. ${ }^{32}$

The reasons for the apparent underutilization of issue severance are a matter for speculation. Perhaps judges with little exposure to this trial technique simply do not consider it. Also, the plaintiffs' bar has been reluctant to consent to issue severance, based on the belief that it may decrease the likelihood of a plaintiff verdict. ${ }^{33}$ Research indicates that this concern may be well founded.

A recent study by Horowitz and Bordens ${ }^{34}$ examined the effect of issue severance in a hypothetical case where all the trial evidence was weighted in favor of the plaintiffs except for general causation evidence, which was ambiguous. The research approach involved exposing the same trial evidence to 128 experimental juries while varying only the structure of the trial. The study found that juries in unitary trials were more likely to interpret the causation evidence in favor of the plaintiff than juries in separate trials. Although the juries in the unitary trials considered each trial decision in sequence, evidence on matters not directly related to the causation issue intruded on the decisionmaking process. At each decision point, the unitary juries looked for other evidence, especially evidence concerning damages, to buttress their decisions. This phenomenon was most evident when juries were faced with the most ambiguous trial issue, general causation. These practices amount to a deviation from and disregard for both the rules of law contained in jury instructions and the jury's sworn duty to determine facts and apply them to these rules of law.

\section{Court-APPOINTEd Experts}

The growth of toxic tort cases and other complex litigation, in which juries must make decisions based upon highly technical or scientific information, has

31. Since 1938, Fed. R. Civil P. 42(b) has permitted separate trials for liability and damage issues for reasons of "convenience or to avoid prejudice." Curry \& Snider, Bifurcated Trials: How to Avoid Them-How to Win Them, TRIAL, Mar. 1988, at 47. In 1966, the Rules were amended to provide an additional reason for the splitting of trials:

The court, in furtherance of convenience or to avoid prejudice, or when separate trials will be conducive to expedition and economy, may order a separate trial of any claim, cross-claim, counterclaim or third-party claim, or of any separate issue or of any number of claims, crossclaims, counterclaims, third-party claims, or issues, always preserving inviolate the right of trial by jury as declared by the Seventh Amendment to the Constitution or as given by a statute of the United States.

FED. R. Civil P. 42(b) (emphasis added).

Research by Aetna's legal department discloses that all states allow bifurcation except Connecticut, Hawaii, Illinois, Louisiana, Nebraska, and New Hampshire. Texas does not permil bifurcation of personal injury suits.

32. Louis Harris \& Associates, Inc., supra note 9, at 744.

33. See Curry \& Snider, supra note 31 , at 47.

34. T. Horowitz \& K. Bordens, An Experimental Investigation of Procedural Issues in Complex Tort Trials (unpublished manuscript 1989) (available at the University of Toledo Department of Psychology). 
created a new set of problems relative to jury effectiveness. As stated by Professor Donald Elliott of Yale Law School:

when we speak of "facts" at issue in toxic tort litigation we are talking about issues of a very different sort than those which our traditional litigation procedures were developed to resolve. Traditionally, common law litigation turned on issues of historical fact-what Professor Alexander Bickel used to call "who struck John" issues-and issues of credibility were left to the common sense of juries. Traditional jury trial procedures may be well-suited to resolving issues of this type. It is questionable at the very least, however, whether traditional courtroom litigation procedures are equally appropriate for resolving issues of toxicology and epidemiology that arise in toxic tort cases. By their very nature, sciences such as these rely on specialized techniques that run counter to a lay persons' common sense intuitions. 95

How well the courts deal with scientific and technical information has had and will continue to have a profound effect on verdicts and settlements in suits that pivot on information of this nature. Unfortunately, as Elliott points out, there are few incentives for getting reliable information to the jury. Instead, the current system creates strong incentives for lawyers to select experts with views outside the mainstream of scientific opinion:

because the current system "extends equal dignity to the opinions of charlatans and Nobel Prize winners, with only a lay jury to distinguish between the two," lawyers are driven to select experts from the extremes out of fear that the jury will probably guess that the truth lies somewhere in between the two. ${ }^{36}$

Elliott identifies clinical ecology as a dramatic example of expert testimony finding its way into the courts despite rejection by the mainstream scientific community. Clinical ecologists argue that exposure to even small amounts of a wide range of chemicals suppresses the immune system, thereby weakening the body's ability to defend against virtually any disease. Although the American Academy of Allergy and Immunology and the California Medical Association have issued statements repudiating clinical ecology, the use of this theory has produced several multimillion dollar jury verdicts as well as numerous large settlements. ${ }^{37}$

The solution proposed by Elliott for problems resulting from the use of unreliable expert testimony is to have a court-appointed expert explain how the scientific community regards the testimony of the party-appointed experts. ${ }^{38}$ This neutral expert would not express opinions on the issues in the case, but would evaluate and criticize the opinions offered by the experts for the parties. ${ }^{39}$

35. D. Elliott, Toward Incentive-Based Procedure: Three Approaches for Regulating Scientific Evidence 2 n.4 (unpublished manuscript 1988) (presented at the Conference on Issues of Civil Procedure: Advancing the Dialogue, Yale Law School Program in Civil Liability, April 8-9, 1988).

36. Id. at 11, 12 (quoting address by Judge Jack B. Weinstein entitled "Role of Expert Testimony and Novel Scientific Evidence in Proof of Causation," American Bar Association Annual Meeting, Aug. 9, 1987).

37. Id. at 5-10.

38. Id. at 25 .

39. Although judges in most courts have the power to appoint impartial experts, the practice is not widely used in personal injury litigation. D. Elliot, supra note 35, at 25-28. 
This approach offers several benefits. First, it exposes the jury to mainstream scientific thinking on the issues. Second, it brings to the process qualified and nonpartisan experts whose knowledge may not otherwise be available to the court. As noted by those who are familiar with the use of expert testimony, "good scientists willing to participate in the process are rare.... '[S]cientists view the adversary process with dismay, distaste, disdain and fear." 40 Also, scientists "have little to gain professionally from becoming involved in a legal suit, and feel conflict between serving the interests of science and those of their client." 41 Although these comments may somewhat overstate the case, many judges have reported that scientists generally respond positively to a request from the court to serve as a neutral witness. ${ }^{42}$

Court-appointed experts also create incentives for the parties to hire sound and credible witnesses. Lawyers are no doubt concerned about the effect on the jury of impartial testimony suggesting that their expert witnesses are incompetent or dishonest.

The use of neutral expert witnesses raises a number of difficult issues: When does it make sense to use a neutral expert? How should judges go about finding an objective, highly qualified expert on the specific issues at hand? Who should pay for the expert? Who should examine the expert before the jury? How should the jury be instructed about testimony they have heard? Perhaps guidance on these matters could effectively be provided to judges through a manual modeled after or appended to the Manual for Complex Litigation. ${ }^{43}$

\section{VI}

\section{Blue Ribbon Juries}

It is inevitable that, regardless of the aids used, some jurors will remain unable to comprehend and evaluate certain information because they lack the necessary background and education. This fact has led Judge Carl Rubin, Chief Judge of the United States District Court for the Southern District of Ohio, to experiment with a procedure he calls the "blue ribbon jury." 44 The procedure involves the selection of jurors on the basis of educational background. Since this procedure has no statutory basis and is not recognized by the Federal Rules of Civil Procedure, it can only be used with the consent of all the parties.

40. See Holden, Science in Court, 243 SCIENCE 1658 (1989) (quoting comments made by Bernard Goldstein of Robert Wood-Johnson Medical School at a seminar entitled "Improving Procedures for Scientific Evidence in Toxic Tort Cases: A Discussion Among Scientists, Judges and Lawyers," Washington, D.C., Mar. 1989).

41. Id. This comment was echoed by other judges at the seminar.

42. Id.

43. Manual for Complex litigation (2d ed. 1985).

44. See C. Rubin, The Blue Ribbon Jury (unpublished manuscript 1989). 
The procedure was used in Highway Equipment Co. v. Caterpillar Co. ${ }^{45}$ a case that involved many complex issues including "the right to sell heavy construction equipment in a given territory, the termination of that right, and the resulting questions of breach of contract, fraud, breach of fiduciary relationship, and other causes of action devised by an exceptionally capable and determined plaintiff's counsel."46

After ranking all potential jurors in order of formal education, an eightmember jury was impaneled. ${ }^{47}$ The jurors had a cumulative education of thirty-three years beyond high school, giving them an average of 4.7 years of higher education. No juror had less than four years of education after high school.

Judge Rubin has commented on the case as follows:

By almost any standard this was an outstanding jury. I cannot recall any other jury that was as attentive, understanding, or conscientious. I watched them with some care to see if they became bored or their interest flagged. This was a technical case and was certainly not dramatic in nature. The jurors' attention was remarkable. . . The jury deliberated less than a day. They reached a defendant's verdict which was fully consistent with the evidence. Despite the valiant, comprehensive, and meticulous presentation by the plaintiff, there was not a basis for a verdict in the plaintiffs favor. ${ }^{48}$

The Louis Harris and Associates poll contains some interesting information about how judges might view this procedure. Sixty percent of federal judges and 55 percent of state judges polled said they questioned whether jurors with differing levels of education could be effective when dealing with complex civil cases. ${ }^{49}$ Only 39 percent of federal judges and 31 percent of state judges, however, said they believed that there should be minimum educational or other qualifications to screen out jurors who cannot understand complex cases. ${ }^{50}$ In what might seem to be a contradictory response, 53 percent of the federal judges and 51 percent of the state judges agreed that in some complex cases, a trial before a panel of experts would be preferable to a trial by jury. ${ }^{51}$ It is possible that the judges disfavored imposing a deviation from the traditional jury trial, but favored expert panels created by stipulation of the parties. Most judges-63 percent of the federal judges and 68 percent of the state judges - believed that a serious study should be made of alternatives to trial by jury for certain types of cases. ${ }^{52}$

45. 707 F. Supp. 954 (S.D. Ohio 1989).

46. C. Rubin, supra note 44 , at 3.

47. Id. Civil juries in the Southern District of Ohio are customarily composed of six persons. In this case, counsel agreed that all jurors impaneled could vote with an understanding that an agreement of six would be dispositive. One member of the eight-person jury was subsequently excused, leaving only seven jurors to deliberate.

48. Id. at 5,7 .

49. See Louis Harris \& Associates, Inc., supra note 9, at 748 .

50. Id.

51. Id.

52. Id 


\section{Conclusion}

Contrary to the claims that insurance companies are striving to subvert or eliminate the jury system, Aetna is actively promoting reforms that would strengthen the system and result in a more equitable and rational jury process. Research indicates that juries can have difficulties executing the responsibilities imposed by the system. This is particularly true in complex litigation. Several devices can help, such as allowing jurors to take notes, giving jurors a pretrial instruction about the issues to be addressed, providing jurors with written copies of the instructions, severing the issues, making greater use of court-appointed experts, and using blue ribbon juries. The usefulness and appropriateness of these devices vary with the type and character of the case to be tried. Further experimentation and evaluation of these devices would be useful. 
